INOBIS: Jurnal Inovasi Bisnis dan Manajemen Indonesia

Volume 03, Nomor 01, Desember 2019

Rorim Panday, Ayuna Suci Hartati,Dovina Navanti

\title{
Queue Systems Evaluation of Fast food Industrial
}

\author{
Rorim Panday* \\ Bhayangkara Jakarta Raya University \\ Ayuna Suci Hartati \\ Bhayangkara Jakarta Raya University \\ Dovina Navanti \\ Bhayangkara Jakarta Raya University \\ *indripan@gmail.com
}

\begin{abstract}
Abstrak
The queuing system can influent customer satisfaction and always interesting to analyze. The queuing at HokBen use a Single Channel Multi-Phase system, 1 service to offer and prepare order menus and 1 cashier. The study was conducted at the Hokben Ujung Menteng Store in East Jakarta, for one week, at 4 sessions during rush hour. After the data obtained, a Single Channel Multi-Phase queue parameter was calculated, namely: the average arrival per unit time, the average service unity of time, the level of server usage, the number of customers in the queue, the number of customers in the system, the waiting time in the queue, the waiting time in the system, and customer probabilities in the system. The result showed that the customer's arrival pattern meets the Poison distribution and the service pattern meets the Normal distribution, but the service time still greater than the standard service time, and of course not satisfy to customers, because they waited a bit longer. After a multi-channel multiphase simulation, which used 2 service lines, the service time smaller than the standard service time, and service more efficient. This research becomes useful for Hokben management specifically, and also for the fast-food industry in general.
\end{abstract}

Keywords: Queue, Single channel single-phase, multi-channel multi-phase

\section{Introduction}

A queue is an event that always happens every day, at various activities, to get a certain service. Queues can occur in activities that produce services or produce products. Long queues occur if the speed of service is slower than the speed of arrival of customers/objects/goods produced. Especially in service operations, the length of the queue will affect the level of customer satisfaction. Therefore a long queue must be sought at a certain level so that customers do not feel they are waiting too long, for example by increasing the number of services, but this will have an impact on operational costs to be incurred by the company. It also does not guarantee that there are no unemployed service facilities due to the absence of people in the queue. Therefore, it is necessary to analyze the problem of queuing to improve service while minimizing the cost of providing service facilities and costs incurred due to customers having to wait to be served(Nosek \& Wilson, 2001).

For a HokBen Fast Food restaurant, consumers can choose and see for themselves the form of food ordered, and one cashier. In this case, HokBen has implemented a Standard Operating Procedure (SOP) queuing system to ensure service quality. Standard Operating Procedure (SOP) which is set including the maximum service time at the counter to customer is 3 minutes for each customer, the maximum service time at the cashier for each customer is 2 minutes, the maximum queue length set by HokBen is 12 people within 60 minutes. The use 
of maximum time and length of the queue is intended as a quality control service at Hokben Ujung Menteng.

With the total time referring to the SOP, it means that the maximum time, until the transaction is completed, is 5 minutes for the average of each customer. According to research conducted for one week, there was an overload of the standard time set. The problem of queuing model and determining the number of queuing lines in the Hokben Ujung Menteng Store service and payment system, East Jakarta, attracted the attention of researchers to conduct research to determine the queuing model and determine the optimal queuing path.

\section{Theory Basis and Hypothesis Development}

A queue is a situation where people or goods in line are waiting to be served. There are 3 components in a queuing system (Ivo Adan and Jacque Resing, 1966)(Dragan \& Jereb, 2014)(Wimbajaya Hamukti, Shabrina, \& M. Ridwan Triantoro, 2015), that are:

a. Size of Arrival Population

b. Arrival patterns on the system

c. Arrival behavior

The queuing process is generally categorized into four basic structures according to the service facilities were mentioned in (Nia Puspita Sari, Sugito, 2016)(Ivo Adan and Jacque Resing, 1966)(Zukerman, 2013)(Heizer, J., \& Render, 2014)(Dragan \& Jereb, 2014)(Hillier \& Lieberman, 2010), that are :

1. Single Channel - Single Phase

2. Single Channel - Multi-Phase

3. Multi-channel - Single Phase

4. Multi-Channel, Multi-Phase

This study, researchers used the Single Channel Multi-Phase model because the Ujung Menteng HokBen Store used a service model where only one path enters the service system and multiple service stages. Formulas for queuing models Single Channel - Single Phase in (Dragan \& Jereb, 2014)(Sztrik, 2012)(Ivo Adan and Jacque Resing, 1966), and the parameter of notations was mentioned in (Carter, Gnendenko, \& Kovalenko, 1990)(Ivo Adan and Jacque Resing, 1966)(Hillier \& Lieberman, 2010)(Taha, 2007), among others :

$\lambda \quad$ : Average number of arrivals per unit time

$\mu \quad$ : Average number of services per unit time

Lq : Average number of waiting in a queue

Ls : The average number of waits in the system

Wq : Average waiting time in queues

Ws : Average waiting time in the system

Ps : Probability of busy service facilities (utilization factor)

P0 : Probability of zero units in the system

Equations for the Single-channel Single Phase and Single-channel Multi-phase Model with Unlimited Populations were mentioned in (Sztrik, 2012)(Heizer, J., \& Render, 2014)(Ivo Adan and Jacque Resing, 1966)(Carter et al., 1990)(Dragan \& Jereb, 2014)(Anokye, Annin, \& Oduro, 2013)(Hillier \& Lieberman, 2010)(Taha, 2007): 
Table 1. Single Channel Single-phase and Single-channel Multi-Phase queue formulas

\begin{tabular}{|c|c|c|c|}
\hline $\begin{array}{l}\mathrm{N} \\
\mathrm{O}\end{array}$ & The count & $\begin{array}{l}\text { Queue formula } \\
\text { M/G/ 1 Model }\end{array}$ & $\begin{array}{l}\text { Queue formula M/M/S } \\
\text { Model }\end{array}$ \\
\hline \multirow[t]{2}{*}{1} & \multirow[t]{2}{*}{ Speed of Arrival Per Session T } & Customer Arrival & Customer Arrival \\
\hline & & Observational Time (Min & Observational Time (Min \\
\hline \multirow[t]{2}{*}{2} & \multirow[t]{2}{*}{ Average Service Speed $(\boldsymbol{\mu})$} & Observational Time (Min & Observational Time (Min \\
\hline & & Customer Arrival & Customer Arrival \\
\hline 3 & $\begin{array}{l}\text { The average number of } \\
\text { customers waiting in a queue }\end{array}$ & $L q=\frac{\lambda}{\mu(\mu-\lambda)}^{2}$ & 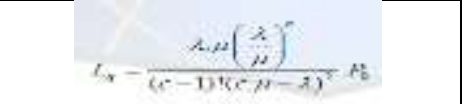 \\
\hline 4 & $\begin{array}{l}\text { The average number of } \\
\text { customers waiting in a system }\end{array}$ & $L s=\frac{\lambda}{\mu-\lambda}$ & $L_{s}=L_{q}+\frac{\lambda}{\mu}$ \\
\hline 5 & $\begin{array}{l}\text { The average waiting time in } \\
\text { queues }\end{array}$ & $W q=\frac{\lambda}{\mu(\mu-\lambda)}$ & $W_{q}=\frac{L_{q}}{\lambda}$ \\
\hline 6 & $\begin{array}{l}\text { The average waiting time in } \\
\text { system (queues }+ \text { service) }\end{array}$ & $\mathrm{Ws}=\frac{1}{(\mu-\lambda)}$ & $W_{s}=\frac{L_{x}}{\lambda}$ \\
\hline 7 & $\begin{array}{l}\text { Probability of busy service } \\
\text { facilities (utilization factor) }\end{array}$ & $\operatorname{Ps}=\rho=\frac{1}{\mu}$ & $P_{s}=\frac{1}{c !}\left(\frac{\lambda}{\mu}\right)^{c} \frac{c \mu}{c \mu-\lambda} P_{0}$ \\
\hline 8 & $\begin{array}{l}\text { Probability of zero units in the } \\
\text { system }\end{array}$ & $P 0=1-\frac{\lambda}{\mu}$ & 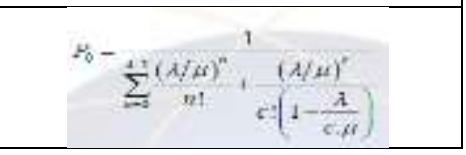 \\
\hline
\end{tabular}

\section{Research Method}

This study used a quantitative approach. The research data were obtained through observations at the Hokben Ujung Menteng Store on Jl. Bekasi Raya KM. 25, Ujung Menteng, Cakung, Kota Jakarta Timur, at four sessions: 12.00 - 13.00, 13.00 - 14.00, 18.00 - 19.00, and $19.00-20.00$, for 7 days, to obtain data on customer arrival time and service time.

Table 2. Queue data

\begin{tabular}{|l|c|c|c|c|c|}
\hline Time & session-1 & & $12.00-13.00$ & \\
\hline \multirow{2}{*}{ Date } & $\begin{array}{c}\text { Queued - } \\
\text { Served } \\
\text { Pivot }\end{array}$ & $\begin{array}{c}\text { Pivot - } \\
\text { Finish } \\
\text { Served } \\
\text { Pivot }\end{array}$ & $\begin{array}{c}\text { Finish Pivot } \\
\text { Served - Start } \\
\text { Served } \\
\text { Cashiers }\end{array}$ & $\begin{array}{c}\text { Start Serving } \\
\text { the Cashier - } \\
\text { Finished } \\
\text { Payment }\end{array}$ & $\begin{array}{c}\text { Time needed } \\
\text { in the } \\
\text { Service }\end{array}$ \\
\cline { 2 - 6 } (Minute) & ( Minute) & Minute) & Minute) & \\
\hline $11 / 2$ & $00: 00: 00$ & $00: 03: 33$ & $00: 02: 52$ & $00: 01: 57$ & $0: 08: 22$ \\
\hline $12 / 2$ & $00: 01: 37$ & $00: 01: 10$ & $00: 01: 13$ & $00: 00: 07$ & $0: 04: 07$ \\
\hline $13 / 2$ & $00: 00: 00$ & $00: 01: 34$ & $00: 00: 59$ & $00: 00: 08$ & $0: 02: 41$ \\
\hline $14 / 2$ & $00: 00: 10$ & $00: 01: 57$ & $00: 00: 15$ & $00: 00: 56$ & $0: 03: 18$ \\
\hline $15 / 2$ & $00: 01: 32$ & $00: 02: 16$ & $00: 01: 24$ & $00: 00: 20$ & $0: 05: 32$ \\
\hline $16 / 2$ & $00: 00: 43$ & $00: 02: 15$ & $00: 00: 47$ & $00: 00: 53$ & $0: 04: 38$ \\
\hline Average & $00: 00: 40$ & $00: 02: 07$ & $00: 01: 15$ & $00: 00: 43$ & $0: 04: 46$ \\
\hline
\end{tabular}


INOBIS: Jurnal Inovasi Bisnis dan Manajemen Indonesia Volume 03, Nomor 01, Desember 2019

Rorim Panday, Ayuna Suci Hartati,Dovina Navanti

\begin{tabular}{|c|c|c|c|c|c|}
\hline Time & \multicolumn{3}{|l|}{ Session-2 } & \multirow{2}{*}{$\frac{13.00-14.00}{00: 00: 44}$} & \multirow[b]{2}{*}{$0: 04: 16$} \\
\hline $11 / 2$ & $00: 00: 20$ & 00:01:40 & $00: 01: 32$ & & \\
\hline $12 / 2$ & 00:00:03 & $00: 02: 32$ & 00:00:38 & 00:00:08 & $0: 03: 21$ \\
\hline $13 / 2$ & 00:00:00 & 00:01:16 & 00:00:37 & 00:00:10 & 0:02:03 \\
\hline $14 / 2$ & $00: 00: 05$ & 00:02:04 & 00:00:46 & 00:00:38 & $0: 03: 33$ \\
\hline $15 / 2$ & 00:00:42 & 00:01:44 & 00:01:51 & 00:00:28 & $0: 04: 45$ \\
\hline $16 / 2$ & $00: 00: 43$ & $00: 02: 15$ & 00:00:47 & 00:01:11 & $0: 04: 56$ \\
\hline Average & 00:00:19 & 00:01:55 & 00:01:02 & 00:00:33 & $0: 03: 49$ \\
\hline Time & \multicolumn{3}{|l|}{ Session-3 } & $18.00-19.00$ & \\
\hline $11 / 2$ & $00: 01: 23$ & 00:03:14 & $00: 02: 45$ & 00:00:26 & $0: 07: 48$ \\
\hline $12 / 2$ & 00:00:00 & 00:04:06 & 00:01:02 & $00: 00: 17$ & $0: 05: 25$ \\
\hline $13 / 2$ & 00:00:00 & 00:02:04 & 00:01:02 & 00:00:10 & $0: 03: 16$ \\
\hline $14 / 2$ & 00:00:09 & $00: 02: 22$ & 00:00:44 & 00:01:38 & $0: 04: 53$ \\
\hline $15 / 2$ & 00:00:07 & 00:01:56 & 00:02:01 & 00:01:37 & $0: 05: 41$ \\
\hline $16 / 2$ & $00: 00: 43$ & $00: 02: 15$ & 00:00:47 & 00:00:53 & $0: 04: 38$ \\
\hline Average & $00: 00: 24$ & 00:02:40 & 00:01:23 & 00:00:50 & $0: 05: 17$ \\
\hline Time & \multicolumn{3}{|l|}{ Session-4 } & $19.00-20.00$ & \\
\hline $11 / 2$ & 00:01:37 & 00:01:10 & 00:01:12 & 00:00:07 & $0: 04: 06$ \\
\hline $12 / 2$ & 00:00:00 & 00:02:05 & 00:00:37 & 00:00:06 & $0: 02: 48$ \\
\hline $13 / 2$ & $00: 00: 25$ & 00:00:26 & 00:01:02 & 00:00:05 & $0: 01: 58$ \\
\hline $14 / 2$ & $00: 01: 15$ & $00: 01: 54$ & 00:01:01 & 00:00:49 & $0: 04: 59$ \\
\hline $15 / 2$ & $00: 00: 17$ & 00:01:42 & 00:01:27 & 00:00:23 & $0: 03: 49$ \\
\hline $16 / 2$ & 00:01:07 & $00: 02: 17$ & 00:01:07 & $00: 00: 33$ & $0: 05: 04$ \\
\hline Average & $00: 00: 47$ & $00: 01: 36$ & 00:01:04 & 00:00:21 & $0: 03: 47$ \\
\hline
\end{tabular}

After the data is obtained, the M / G / 1 and M / M / S calculation stages are as follows:

1. Find out $\lambda$ and $\mu$.

2. Perform distribution compatibility test

a. Arrival distribution test

b. Service distribution test.

3. (M/G/1) Analysis for:

a. The average waiting time in queues (Wq)

b. The average number of customer waiting in a queue (Lq)

c. The average number of customers waiting in a system (Ls)

d. The average waiting time in system (Ws)

4. Analyzing optimal service levels

5. Make conclusions from the results of research

Following are some of the studies using single-channel multi-phase conducted by (Daniel, Victor, Ngozi, \& N, 2014) at Shoprite Plaza Enugu State, Nigeria, (Agyei, Asaredarko, \& Odilon, 2015) on the queue system at Ghana Commercial Bank Ltd. Kumasi Main Branch, (Maslahah, 2011) analyzes Single Channel - Multi-Phase queue models from various literature. Some other studies, more using M / M / S models as conducted by (Mahanani, 2017) on the Queue System at PT. Bank Negara Indonesia UGM Yogyakarta Branch Office, (Ginting, 2013) on the $X$ bank queue system in the city of Semarang, (Prastiyo, 2017) on the 
Queue System at Supermarkets in South Lampung, (Sari, 2013) at the Queue at Gajah Mada Jember Public Fuel Station (SPBU), (Putranto, 2014) in the Yogyakarta Samsat Office Queue System. While research conducted by (Verdika, 2016) on the queuing system at the gas station Jl. Sunset Road Kuta Badung Bali, and (Serlina, 2018) in the Customer Queue System at the Bank Rakyat Indonesia (BRI) Bandar Lampung Branch, are using Multi-channel single phase.

\section{Discussions}

The level of service provided to each customer at the facility relatively is not same, because there are customers who require a long time, some are quite long but there are also those who require a short amount of time, this happens because the needs of each customer are different. In this calculation, the average taken can be used as a basis for consideration.

Table 3. The results of the calculation of the speed of arrival and speed of service

\begin{tabular}{|l|l|l|}
\hline & \multicolumn{1}{|c|}{ Arrival Speed per customer } & \multicolumn{1}{c|}{ Average service speed $(\boldsymbol{\mu})$} \\
\hline & $\lambda 1: \frac{15}{60 \text { Minute }}=0.25$ Minute & $\mu 1: \frac{60 \text { Minute }}{15}=4.00$ Minute \\
\hline & $\lambda 2: \frac{13}{60 \text { Minute }}=0.22$ Minute & $\mu 2: \frac{60 \text { Minute }}{13}=4.62$ Minute \\
\hline & $\lambda 3: \frac{12}{60 \text { Minute }}=0.20$ Minute & $\mu 3: \frac{60 \text { Minute }}{12}=5$ Minute \\
\hline & $\lambda 4: \frac{9}{60 \text { Minute }}=0.15$ Minute & $\mu 4: \frac{60 \text { Minute }}{9}=6.67$ Minute \\
\hline
\end{tabular}

For testing the distribution of arrivals and services using the Kolmogorov Smirnov test on SPSS ver23. From the results of testing the distribution of customer arrivals with Poisson distribution, with a significant level of 0.184 . The Exponential Distribution Test results illustrate that customer service data are in line and the service stage has no Exponential distribution. Because the significance value is smaller than the real level of 0.034, 0.020, 0.051, $0.019<0.05$. So H1 was rejected. Furthermore, based on testing using SPSS that is using the Goodness of fit test obtained data with Normal distribution, with a significance level or p-value of 0.200 for sessions $1-3$ and 0.056 for session 4 .

\section{Analysis of the M / G / 1 Model Queue System}

Table 4 Calculation of the M / G / 1 Model

\begin{tabular}{|c|c|c|c|c|c|c|}
\hline Sesi & $\mathrm{P}$ & $\mathrm{Lq}$ & $\mathrm{Ls}$ & $\mathrm{Wq}$ & $\mathrm{Ws}$ & Po \\
\hline 1 & 0.06 & 1.38 & 1.44 & 5.51 & 5.76 & 0.94 \\
\hline 2 & 0.05 & 1.84 & 1.88 & 8.35 & 8.56 & 0.95 \\
\hline 3 & 0.04 & 1.04 & 1.08 & 5.20 & 5.40 & 0.96 \\
\hline 4 & 0.02 & 0.67 & 0.69 & 4.47 & 4.62 & 0.98 \\
\hline
\end{tabular}

Source: Data processed

The highest level of server used in serving customers was in session 1, while the lowest was in session 4. In session 1, the number of customers was the most compared to other sessions. The expected length of the queue is 1 person in session 4 and 2 people in session 2 . Likewise the length of the queue in the system, the lowest is in session 4 by 1 person, while the most there are 2 people in session 2. The length of time a customer waits in a queue is between 5 minutes in session 4 and 8.5 minutes in session 2. Likewise, the length of time a 
customer waits in the system. The probability of people in the queue approaching 1 , can be interpreted there are still people in the queue.

\section{Analysis of the M / M / S Model Queue System}

Table 5. Calculation of the M / M / S Model

\begin{tabular}{|c|c|c|c|c|c|c|}
\hline Session & $\mathrm{P}$ & $\mathrm{Lq}$ & $\mathrm{Ls}$ & $\mathrm{Wq}$ & $\mathrm{Ws}$ & $\mathrm{Po}$ \\
\hline 1 & 0.03 & 0.00 & 0.06 & 0.00 & 0.25 & 0.00 \\
\hline 2 & 0.02 & 0.00 & 0.05 & 0.00 & 0.22 & 0.00 \\
\hline 3 & 0.02 & 0.00 & 0.04 & 0.00 & 0.20 & 0.00 \\
\hline 4 & 0.01 & 0.00 & 0.02 & 0.00 & 0.15 & 0.00 \\
\hline
\end{tabular}

Source: Data processed

a. Server usability level (P)

The level of server use in serving customers is sought by using the M / M / S equation. So the opportunity level of service server service staff serving customers in each session is between 0.01 to 0.03 . This illustrates that the more customer arrivals, the server service level of service officers serving customers is increasing in accordance with the value obtained from the calculation of the level of server use.

b. Queue Length Expectations (Lq)

The average queue length in the service process is calculated using the M / M / S equation. So the average length of the queue during the service process in each session is 0.00 Customers in minutes, which means that there is no queue during the service process. Due to the addition of one server, the queue process becomes faster which affects the reduced length of the queue.

c. Expectations in the system (Ls)

The process of customer arrival and length of service until finally leaving the service facility can be determined by the average number of customers queuing in the queuing system and calculated using the M / M / S equation. So, the average customer queuing from the arrival process to the end of service in each session is between 0.02 and 0.06 . The result is that because one server is added, the queue process becomes faster which affects the reduced queue length.

d. Waiting Time in the Queue (Wq)

The average waiting time for a customer to be served by service personnel is calculated using the M / M / S equation. The average waiting time for a customer before serving in each session is 0.00 . This means that there is no waiting time during the service process, because the addition of one server makes the queue process faster which affects the reduced waiting time for customers.

e. Waiting Time in the System (Ws)

The process of customer arrival and length of service until finally leaving the service facility can be determined how the average waiting time for customers in the queuing system is calculated using the M / M / S equation. So the average waiting time for a customer from the arrival process to the end is served in each session that is between 0.15 to 0.25 , reducing the time in the system with the addition of a server.

f. Probability of 0 people in the queue (P0) 


\section{Rorim Panday, Ayuna Suci Hartati,Dovina Navanti}

The probability that there are 0 people in the queue is calculated using the $\mathrm{M} / \mathrm{M} / \mathrm{S}$ equation. So the average probability there are 0 people in the queue of a customer, meaning there are no people in the queue.

Based on the analysis results it can be seen that the queuing model applied by the Hokben Ujung Menteng Store is Single Channel-Multi Phase. Based on the results of calculations with a single line queue system model, it is found that the facility lines currently applied at the Menteng end Hokok store are still less than optimal because based on the countdown on waiting time in the system and waiting time in the customer queue, the results exceed the standard service time set by the company, namely 5 minutes for one customer. For Wq in each data collection session, the results for the 1st session were 5.51 minutes, the 2 nd session was 8.35 minutes, the 3rd session was 5.20 minutes and the 4th session was 4.47 minutes. After that for Ws in each session, the results were obtained, the 1st session was 5.76 minutes, the 2 nd session was 8.56 minutes, the 3 rd session was 5.40 minutes, and the 4th session was 4.62 minutes.

The cause of the problem is the capacity of the number of facility lines is not balanced with the capacity of the number of customers who come during the rush hour period so that the performance of services with 1 facility line is considered less than optimal. For this reason, a solution is needed so that service performance becomes optimal, so that service time at a certain time can be overcome.

Quality of service can be overcome by adding one facility line, to 2 facility lines. Based on the simulation if a new queuing model is applied, namely Multi-Channel Multi-Phase with M / M / 2 queuing pattern, the service time will be faster compared to one service line. The optimal number of facility lines at Menteng Ujung Hokok store is 2 facility lines. The results obtained from the calculation of service level, there is an increase in service level when the number of facility lines is added by 1 . In the 1 st session period, the service time needed before the addition of facility lines is Wq 5.51 minutes and Ws 5.76 minutes while after the addition of facility lines the time required is Wq 0.00 minutes and Ws 0.25 minutes. In the 2 nd session period, the service time needed before the addition of facility lines is Wq 8.35 minutes and Ws 8.56 minutes while after the addition of facility lines the time required is $\mathrm{Wq} 0.00$ minutes and Ws 0.22 minutes. In the 3rd session period, the service time needed before the addition of facility lines is Wq 5.20 minutes and Ws 5.40 minutes while after the addition of facility lines the time required is Wq 0.00 minutes and Ws 0.20 minutes. In the 4 th session period, the service time needed before the addition of facility lines is $\mathrm{Wq} 4.47$ minutes and Ws 4.62 minutes while after the addition of facility lines the time required is Wq 0.00 minutes and Ws 0.15 minutes. The average service time of the four sessions needed before the addition of facility lines is $\mathrm{Wq}$ 5.56 minutes and Ws 5.76 minutes while after the addition of the facility lines the time required is $\mathrm{Wq} 0.01$ minutes and Ws 0.21 minutes.

Based on calculations using a single line queue system model, the waiting time in the queue and the waiting time in the system is needed with 1 facility lane during the rush hour period, which is the average of 4 data collection sessions at 12.00-13.00 13.00-14.00 18.0019.00 and $19.00-20.00$ for Wq 5.56 and Ws 5.76 minutes with an average customer arrival of 49 people. Service performance in the menu purchase transaction process can be overcome by adding one facility line (to 2 facility lines) during the peak hour period, so service time at 2 facility lines is faster than before the addition of facility lines. The service time needed by the Menteng Hokben store at 2 facility lines is Wq 0.00 minutes and Ws 0.21 minutes so that the performance of the service system with 2 facility lines at peak hours is better. Besides, the length of the queue (Lq) is 0.00 -minute unity customers which illustrate that there is no queue because all customers can be directly served without waiting for the queue. Thus increasing the number of service lines improves the service process. 
Also, an increase in efficiency by making changes to the queuing model is as follows:

Table 6. Efficiency Change in the Queue Model

\begin{tabular}{|c|c|c|c|c|c|c|}
\hline \multicolumn{7}{|c|}{$\mathrm{M} / \mathrm{G} / 1$} \\
\hline Sesi & P & Lq & Ls & Wq & Ws & Po \\
\hline 1 & 0.06 & 1.38 & 1.44 & 5.51 & 5.76 & 0.94 \\
\hline 2 & 0.05 & 1.84 & 1.88 & 8.35 & 8.56 & 0.95 \\
\hline 3 & 0.04 & 1.04 & 1.08 & 5.2 & 5.4 & 0.96 \\
\hline 4 & 0.02 & 0.67 & 0.69 & 4.47 & 4.62 & 0.98 \\
\hline \multicolumn{7}{|c|}{$\mathrm{M} / \mathrm{M} / \mathrm{S}$} \\
\hline Sesi & P & Lq & Ls & Wq & Ws & Po \\
\hline 1 & 0.03 & 0 & 0.06 & 0 & 0.25 & 0 \\
\hline 2 & 0.02 & 0 & 0.05 & 0 & 0.22 & 0 \\
\hline 3 & 0.02 & 0 & 0.04 & 0 & 0.2 & 0 \\
\hline 4 & 0.01 & 0 & 0.02 & 0 & 0.15 & 0 \\
\hline \multicolumn{7}{|c|}{ EFISIENSI } \\
\hline Sesi & P & Lq & Ls & Wq & Ws & Po \\
\hline 1 & 0.5 & 1 & 0.95833 & 1 & 0.9566 & 1 \\
\hline 2 & 0.6 & 1 & 0.9734 & 1 & 0.9743 & 1 \\
\hline 3 & 0.5 & 1 & 0.96296 & 1 & 0.96296 & 1 \\
\hline 4 & 0.5 & 1 & 0.97101 & 1 & 0.96753 & 1 \\
\hline
\end{tabular}

After simulating a change in the queuing model, there was an increase in efficiency in the session time reaching $50 \%$ to $100 \%$ in all sessions and from the average time increased to $90 \%$ to $100 \%$ of the data taken during observation. With multi-channel multi-phase, theoretically and empirically, it will improve service quality; however, at times that are not rush hour facilities are likely to be large idle. Therefore it is necessary to take into account the use of the system in terms of the cost of the idle system and in terms of benefits that are not too many when not busy hours. Another alternative, still using single-channel multi-phase, by adding services to the service menu and the cashier. Thus serving 2 people and there are 2 cashiers. This study becomes even more interesting in the continuation of this research. However, this research is very useful for Hokben's management in increasing service, and also for the fast-food industry in general.

\section{Conclusions}

Based on the results of research and discussion obtained, several conclusions can be drawn as follows:

- By implementing a single-phase single channel, it turns out that the service time that occurs is greater than the standard service time set, so that the single-phase singlechannel service is not optimal, and has not yet satisfied the customer, because there are customers who wait a bit longer.

- By conducting multi-channel multiphase simulations, in the sense of adding service lines, the service time that occurs is faster than the service time with a single-phase single channel, in the four service sessions.

- By conducting multi-channel multi-phase simulations, there is an increase in efficiency in terms of service time.

\section{Recommendation}

With the result that multi-channel multi-phase simulations are more efficient than single-phase single channel, the researchers suggest that Hokben's management should consider using multi-channel multi-phase in the queuing service system in Hokben during peak hours. 


\section{References}

Agyei, W., Asare-darko, C., \& Odilon, F. (2015). Modeling and Analysis of Queuing Systems in Banks: A case study of Ghana Commercial Bank Ltd. Kumasi Main Branch. International Journal of Scientific \& Technology Research, 4(07), 160-163.

Anokye, M., Annin, K., \& Oduro, F. T. (2013). Application of Queuing Theory to Vehicular Traffic at Signalized Intersection in Kumasi-Ashanti Region, Ghana, 3(7), 23-29.

Carter, J. M., Gnendenko, B. V., \& Kovalenko, I. N. (1990). Introduction to Queueing Theory. The Mathematical Gazette, 74(470), 409. https://doi.org/10.2307/3618175

Daniel, E. C., Victor, O. A., Ngozi, U. M., \& N, M. N. (2014). Analysis Of Queuing System Using Single-Line Multiple Servers System: A Case Study Of Shoprite Plaza Enugu State, Nigeria. International Journal of Scientific \& Technology Research, 3(3), 364-374.

Ginting, P. L. (2013). Analisis Sistem Antrian dan Optimalisasi Layanan Teller. Diponegoro.

Heizer, J., \& Render, B. (2014). Operations Management (7th edition). New Jersey: Pearson Education. Dragan, D., \& Jereb, B. (2014). Working paper INTRODUCTION TO QUEUING MODELS Dejan Dragan Borut Jereb. Working Paper, (June 2013).

Hillier, F. S., \& Lieberman, G. J. (2010). Introduction to Operation Research (Ninth Edit). New York: McGraw-Hill.

Ivo Adan and Jacque Resing. (1966). Queueing systems. Automatica, 3(3-4), 231-244. https://doi.org/10.1016/0005-1098(66)90015-X

Mahanani, A. (2017). ANALISIS SISTEM ANTRIAN PADA PT. BANK NEGARA INDONESIA KANTOR CABANG UGM YOGYAKARTA. UNIVERSITAS ISLAM NEGERI SUNAN KALIJAGA YOGYAKARTA.

Maslahah, L. (2011). ANALISIS MODEL ANTRIAN SINGLE CHANNEL - MULTI PHASE. UNIVERSITAS ISLAM NEGERI (UIN) MAULANA MALIK IBRAHIM MALANG.

Nia Puspita Sari, Sugito, B. W. (2016). Penerapan Teori Antrian Pada Pelayanan Teller Bank X Kantor Cabang Pembantu Puri Sentra Niaga. JURNAL GAUSSIAN, 6(1), 81-90.

Nosek, J., \& Wilson, J. P. (2001). Queuing theory and customer satisfaction: A review of terminology, trends, and applications to pharmacy practice. Hospital Pharmacy, 36(3), 275-279. https://doi.org/10.1177/001857870103600307

Prastiyo, Y. (2017). Evaluasi Penerapan Sistem Antrian Pada Swalayan Fitrinof Lampung Selatan. Bandar Lampung: Universitas Lampung.

Putranto, M. A. (2014). Analisis Masalah Sistem Antrian Model Multi Phase Pada Kantor Samsat Yogyakarta. UNIVERSITAS NEGERI YOGYAKARTA.

Sari, N. S. (2013). Analisis Teori Antrian Padaf Stasiun Pengisian Bahan Bakar Umum (Spbu) Gajah Mada Jember. Jurnal Ekonomi, 6.

Serlina, L. (2018). Analisis Sistem Antrian Pelanggan Bank Rakyat Indonesia (Bri) Cabang Bandar Lampung Menggunakan Model Antrian Multi Channel-Single Phase. Philosophical Transactions of the Royal Society B: Biological Sciences, 356(1408), 421435. https://doi.org/10.1098/rstb.2000.0775

Sztrik, J. (2012). Basic Queueing Theory. Budapest. 
INOBIS: Jurnal Inovasi Bisnis dan Manajemen Indonesia

Volume 03, Nomor 01, Desember 2019

Rorim Panday, Ayuna Suci Hartati,Dovina Navanti

Taha, H. A. (2007). Operations Reserach An Introduction (Eigth Edit). New Jersey 07458: Prentice Hall.

Verdika, Y. (2016). Model Antrian Multi Channel Dengan Pola Kedatangan Poisson. UNIVERSITAS ISLAM NEGERI MAULANA MALIK IBRAHIM MALANG.

Wimbajaya Hamukti, F. N. W., Shabrina, R., \& M. Ridwan Triantoro. (2015). Tugas Besar Jurnal Kajian Tol Buah Batu Menggunakan Metode Antrian Pada Bulan Desember 2015.

Zukerman, M. (2013). Introduction to Queueing Theory and Stochastic Teletraffic Models. Retrieved from http://arxiv.org/abs/1307.2968 